\title{
Community Perception on Sustainable Utilization of Kaduwela Wetland for Agriculture, Sri Lanka
}

\author{
W. R. M. D. P. Nawarathne, S. P. Dissanayake*, and G. A. S. Ginigaddara
}

Department of Agricultural Systems, Faculty of Agriculture, Rajarata University of Sri Lanka, Anuradhapura (50000), Sri Lanka.

\section{Correspondence:}

*disasampa@yahoo.com

ORCID:0000-0001-7212-2734

\begin{abstract}
Wetlands serve as valuable natural infrastructure for agriculture for million years. Food security is a global issue of all nations in the world; especially the developing countries. Demand driven agricultural expansion encroaches natural habitats in urban and rural peripherals in developing countries. This study was conducted to investigate community perception towards upland crop cultivation during the dry season in urban Kaduwela wetland. A structured questionnaire was administered to the farmers to collect information. The results of the factor analysis revealed that concerns in agricultural supportive services, irrigation, marketing and technology as major risks and constraints. According to the results of the binary logistic regression; land extent \{Odds Ratio $(\mathrm{OR})=0.387\}$, knowledge on environment friendly farming practices $(\mathrm{OR}=0.070)$, knowledge on traditional farming practices $(\mathrm{OR}=14.696)$, farming experience of the household head $(\mathrm{OR}=1.126)$, and access to extension services by the farmers $(\mathrm{OR}=0.202)$ were recognized as positively influencing factors $(p<0.05)$. Provision of regular and reliable extension service for choosing of a right crop and self-generating of quality planting materials could be recommended for sustainability of the upland agricultural system in urban Kaduwela wetland.
\end{abstract}

Keywords: Farmer perception, Upland crop cultivation, Odds ratio, Wetland 


\section{Introduction}

Wetlands are lands in which water has a major influence on the soil, plant, and animal life at least a certain period of a year. In simply, it is a sink of surface and underground water flows. Wetlands are lower elevation and higher in water table. According to the Ramsar Convention; wetlands are "areas of marsh, fen, peatland or water, whether natural or artificial, permanent or temporary, with water that is static or flowing, fresh, brackish or salt, including areas of marine water the depth of which at low tide does not exceed six meters" (Ramsar Convention Secretariat 2013). Climate, topography and soil drainage are the factors interacting during wetland formation. Seasonal wetlands are known as isolated freshwater wetlands. These are inundated seasonally by rains and then dry; thus, surface water is not permanent in seasonal wetland. These wetlands are dominated by herbs adapted to waterlogged conditions or seasonally wet soils (Anon 1999). Provision of clean water and food, retention of soil and cycling of nutrients, climate regulation, and flood regulation are some ecosystem services by wetlands. Wetlands contribute to the livelihoods of millions of people in numerous ways. Wetland agriculture is very much significant for poverty reduction, food security, and facilitating diversification of rural livelihoods in identified wetlands. For thousands of years, wetlands have been used for agriculture. Efficient wetland agricultural systems may provide income and a significant impact on self-sufficiency through crop cultivation for adjacent farming community
(Ajewole 2014). Farmers develop irrigated vegetable gardens in uplands of wetlands in the dry season. Wetlands contribute to livelihoods in terms of direct cash income and food security (Masiyandima et al. 2004). In Malawi, 36\% of the population of the country grows their food on wetlands (Nyamadzawo 2015). Both formal and informal irrigation is used in wetland agriculture in certain countries (Msusa 2011). Cultivation of upland crops during the dry season and paddy in the wet season is a successful strategy of the utilization of seasonal wetlands (Ajewole 2014). Hydrological conditions prevailing in wetlands are favourable for rice production and production of upland crops during the dry season (Izac et al. 1990).

Suitability of a wetland for agriculture depends on wetland characteristics and socio-economic characteristics of the neighbouring local community. Soil characteristics, climate, and socio-economic characteristics of the neighbouring community; age, gender, farming experience, economic level, dependence on farming were the primary determinants (Mc Cartney and Houghton-Carr 2009).

Dry season wetland farming is highly significant in sustaining the livelihoods of farmers throughout the year and achieving food security. Although, dry season wetland farming has benefits like achieving food security and providing an income, poor cultivation practices can reduce soil fertility and harm hydrological cycles and biodiversity of wetlands (Nyamadzawo et al. 2015). Therefore, sustainable wetland cultivation is needed, while having optimum benefits for the community. 
The wetland agriculture is more controversial, and uncontrolled wetland exploitation can damage the ecosystem (Clarke 2012). The major threats for wetlands by agriculture are overexploitation of resources and facilitation of drainage. Therefore, wise use of wetlands in agriculture is very important for sustainable utilization.

Kaduwela wetland is a seasonal wetland that is situated in the Dedigamuwa GN division in Kaduwela DS division, Colombo District, Western Province. The total area of wetland is 110 acres and at present 25 acres have been abandoned. This wetland has identified as a seasonal wetland, because the inundation is prevailing in one season, while other season is dry. Typically, in Yala season, the fields are flooded due to South West Monsoonal rains and mostly paddy is the main crop grown. In Maha season, the fields are dry and both upland crops and paddy are cultivated with the North East Monsoonal rains.

At present, the largest wetland area; which is known as "Maha-wela" is an underutilized land. Lands owned by the farmers in surrounding of Maha-wela wetland cultivates their lands. During the time the survey, farmers cultivated rice in lowland areas and upland crops in upland areas. Leafy vegetables like Gotukola (Centella asiatica), tuber crops like Kiriala (Xanthosoma sagittifolium), fruit crops like Papaya (Carica papaya) and Banana (Musa spp.) are some upland crops cultivated by farmers. This seasonal wetland cultivation is very much essential for smallholder farming communities in the Kaduwela area to sustain and diversify their livelihoods throughout the year.

Due to floods, crops like paddy can only be cultivated in this wetland during wet season. More often, farmers unable to cultivate paddy in Maha season due to less rains, lack of irrigation facilities, pest and disease problems, and weed infestation. Since this wetland is located in the Western Province, the North-East monsoon does not bring enough water for paddy cultivation. Moreover, there is no infrastructure for o irrigation like tanks and canals. Presently, farmers are requesting for a better solution for irrigational issues. Even in Yala season, paddy cannot be grown successfully, due to heavy South-West monsoonal rains and severity of floods. Pests and diseases and weed infestation are also severe during wet seasons. Therefore, farmers should have a solution for sustenance and improved household food security. Upland crops like root \& tubers, vegetables, and leafy vegetables do not require water or irrigation similar to paddy. Upland crop cultivation could be a solution for the water scarcity problem during the dry seasons; thus, sustenance can be achieved. Cultivation of upland crops and paddy in Maha season can be successful strategy. Upland crop cultivation is done on a small scale at present. Concurrently, there is a need to identify the community preferences towards upland crop cultivation to expand it further.

There is a significant potential in the neighbouring community for successful cultivation of upland crops. However, farmers do not satisfactorily use resources and 
potentials. Some farmers have abandoned agriculture due to issues of irrigation. A solution such as upland farming may attract farmers to agricultural again. It can be a new employment strategy and a livelihood diversification method. Furthermore, upland farming will ensure food security among the neighbouring community by supplying foods and an income throughout the year.

For establishing specific upland crop cultivation, evaluation of the current status of crop cultivation, and farmers' opinion towards the utilization of Kaduwela wetland for upland crop cultivation are needed to identify. Generally, involvement of local community is now recognized as a precondition in successful planning and management of wetland resources for livelihood security (Ramsar Convention Secretariat 2004).

Therefore, this research was conducted in searching of community perception on sustainable utilization of wetlands for upland crops.

\section{Methodology}

Dedigamuwa Grama Niladhari (GN) division was purposefully selected for this study. The target population was 120 farmers of Mahasen farmer organization in the Dedigamuwa GN division. Dedigamuwa GN division is located in Kaduwela Divisional Secretariat, Colombo district, Western Province ( $\left.6^{\circ} 89^{\prime} \mathrm{N} 80^{\circ} 02^{\prime} \mathrm{E}\right)$. The population of the Dedigamuwa GN division is 2,105 (Ministry of Home Affairs 2019).

Primary and secondary data were assessed in this study. Primary data was collected using a pre-tested questionnaire survey and field observations. The questionnaires were aimed to assess the community perception on cultivation of upland crops and to explore the present status of upland crop cultivation in this area. A structured questionnaire was designed to collect information on potentials, risks, constraints, community preference, and present upland crop cultivation. Secondary data such as rainfall and air temperature for past 20 years were collected from Department of Meteorology, Sri Lanka. Collected data were analysed using descriptive statistics, factor analysis, and binary logistic regression model. Factor analysis was used in analysing risks and constraints. Community preferences towards risks and constraints were measured using a 5point Likert scale $(1=$ Completely disagree, $2=$ Disagree, 3 = Moderate, $4=$ Agree, $5=$ Completely agree). A major risk and a least risk were identified. The binary logistic regression model was used to identify the factors affecting the community perception to cultivate upland crops in the Kaduwela wetland.

The farmer group was divided into two groups; i.e. i. farmers willing to cultivate and ii. not willing to cultivate. The dependent variable was explained as willingness to cultivate (Yes=1) and no willingness to cultivate $(\mathrm{No}=0)$ with different independent variables. The model that describes the preference of the community on cultivating upland crops can be given as,

$$
\text { Logit } Y=\beta_{0}+\beta_{1} X_{1}+\beta_{2} X_{2}+\beta_{3} X_{3}+. .+\beta_{n} X_{n}+\text { error }
$$

where;

Logit $Y=$ Dependent variable (perception on cultivating upland crops) 
$\beta_{0}=$ Intercept

$\beta_{1}$ to $\beta_{n}=$ Partial regression coefficients

$X_{1}$ to $X_{n}=$ Explanatory variables

In this study, both continuous and categorical variables were used.

\section{Results and Discussion}

The socio-economic characteristics of respondents are described in table 1 . The

Table 1: Socioeconomic Characteristics of Respondents

\begin{tabular}{|c|c|c|c|}
\hline $\begin{array}{l}\text { Socio-economic } \\
\text { characteristic }\end{array}$ & Category & $\begin{array}{l}\text { Farmers who are willing to } \\
\text { cultivate upland crops in } \\
\text { Kaduwela wetland (\%) }\end{array}$ & $\begin{array}{l}\text { Farmers who are not willing } \\
\text { to cultivate upland crops in } \\
\text { Kaduwela wetland (\%) }\end{array}$ \\
\hline \multirow{5}{*}{ Age (years) } & $30-39$ & 9 & 15 \\
\hline & $40-49$ & 25 & 25 \\
\hline & $50-59$ & 29 & 33 \\
\hline & $60-69$ & 25 & 17 \\
\hline & $>=70$ & 12 & 10 \\
\hline \multirow{2}{*}{ Gender } & Male & 87 & 90 \\
\hline & Female & 13 & 10 \\
\hline \multirow{5}{*}{$\begin{array}{l}\text { Education } \\
\text { (years) }\end{array}$} & No education & 3 & 0 \\
\hline & $1-5$ & 4 & 2 \\
\hline & $6-10$ & 65 & 65 \\
\hline & $11-13$ & 25 & 25 \\
\hline & $>13$ & 3 & 8 \\
\hline \multirow[t]{5}{*}{ Occupation } & Farming & 20 & 6 \\
\hline & Govt. employee & 12 & 25 \\
\hline & Private sector employee & 28 & 33 \\
\hline & Self-employee & 25 & 23 \\
\hline & Non-agricultural labour & 15 & 13 \\
\hline
\end{tabular}

Source: Field Survey (2019)

The potentials to utilize Kaduwela wetland for upland crop cultivation are described in Table 2. According to the views of farmers', those who are willing to participate upland crop cultivation have some training on upland farming, knowledge on traditional farming practices, and knowledge on majority of the respondents of both groups were belonging to the age group of 50-59 years and were male dominant. A higher percentage of respondents have their education up to grade 6 to 10. Majority of the farmers of both groups were private-sector employees. 
Table 2: Potentials to Utilization of Kaduwela Wetland for Upland Crop Cultivation

\begin{tabular}{|c|c|c|c|c|}
\hline \multirow{3}{*}{ Potentials } & \multicolumn{4}{|c|}{ Farmers' response } \\
\hline & \multicolumn{2}{|c|}{$\begin{array}{l}\text { Willing to cultivate } \\
\text { upland crops }\end{array}$} & \multicolumn{2}{|c|}{$\begin{array}{c}\text { Not willing to } \\
\text { cultivate upland } \\
\text { crops }\end{array}$} \\
\hline & Yes (\%) & No (\%) & Yes (\%) & No (\%) \\
\hline Presence of the second generation to continue farming activities & 38 & 62 & 10 & 90 \\
\hline Formal training in upland farming & 100 & 0 & 50 & 50 \\
\hline Knowledge of traditional farming practices & 75 & 25 & 17 & 83 \\
\hline Knowledge on environment-friendly organic farming practices & 94 & 6 & 31 & 69 \\
\hline Availability of insurance scheme & 97 & 3 & - & - \\
\hline Usage of animal/organic manure & 99 & 1 & - & - \\
\hline The practice of crop rotation & 76 & 24 & - & - \\
\hline Usage of cover crops and mulch & 60 & 40 & - & - \\
\hline
\end{tabular}

Source: Field Survey (2019)

The factor analysis (Table 3) revealed that supportive services related factors namely lack of extension services, infrastructure problems, lack of public infrastructure, and lack of information and assistance on proper land use have large positive loadings on factor 1 indicating that these factors are the risks and constraints in utilization of Kaduwela wetland upland crops. Further, the second factor was negatively loaded; water scarcity related issues; combining water scarcity during Maha season and physical irrigation issues. The third factor; technological issue of farmers was negatively loaded with lack of technology for upland crop cultivation. Price fluctuation and transport problems have large positive loadings on factor 4 , which describes marketing issues of the farmers.

Table 3: Factor, Factor Variables and Factor Loading of Factor Analysis

\begin{tabular}{llc}
\hline \multicolumn{1}{c}{ Factor } & \multicolumn{1}{c}{ Variable } & Factor Loading \\
\hline 1. Constraints in & Lack of extension services & 0.902 \\
supportive services & Lack of public infrastructure & 0.738 \\
& Lack of information and assistance on proper land use & 0.791 \\
& Infrastructure problems & 0.908 \\
\hline 2.Water scarcity issue & Water scarcity during Maha season & -0.931 \\
& Physical irrigation issues & -0.845 \\
\hline 3. Technological issue & Lack of technology & -0.830 \\
\hline 4. Marketing problems & Price fluctuation & 0.849 \\
\hline
\end{tabular}

Source: Field Survey (2019) 
The binary logistic regression results (Table 4) revealed that land extent, knowledge on environment-friendly farming practices, knowledge on traditional farming practices, farming experience, access to extension services $(p<0.05)$ and occupation of the household head $(p<0.1)$ were significantly affecting for the preference to cultivate upland crops by the farmers in Kaduwela wetland area.

The results proved that when holding size is greater than 1 acre (OR $=0.39$ ), most of the farmers who are not cultivating at present tend to cultivate. When farmers enhance their knowledge about environmentfriendly farming practices $(\mathrm{OR}=0.07)$ and traditional farming practices $(\mathrm{OR}=14.69)$, non-cultivating farmers have a tendency to move towards cultivation. When farmers have greater farming experiences $(\mathrm{OR}=$ 1.13) and more access to extension contacts $(\mathrm{OR}=0.202)$, they are more likely to cultivate crops. Farmers, who are government employees $(\mathrm{OR}=0.35)$ were more likely to cultivate upland crops, which may be due to the regular income to maintain the management practices continuously.

Table 4: Binary Logistic Regression Results

\begin{tabular}{|c|c|c|c|c|}
\hline \multicolumn{2}{|c|}{ Variable } & \multirow{2}{*}{$\frac{p>\text { chi sq. }}{0.03^{*}}$} & \multirow{2}{*}{$\begin{array}{c}\text { Odd ratio } \\
0.39\end{array}$} & \multirow{2}{*}{$\begin{array}{c}\mathbf{9 5 \%} \text { confidence limits } \\
0.16-0.91\end{array}$} \\
\hline Land extent & & & & \\
\hline $\begin{array}{l}\text { Knowledge on environment } \\
\text { friendly farming practices }\end{array}$ & 1 vs 0 & $0.01^{*}$ & 0.07 & $0.01-0.52$ \\
\hline $\begin{array}{l}\text { Knowledge on traditional } \\
\text { farming practices }\end{array}$ & 1 vs 0 & $0.002^{*}$ & 14.70 & $2.5-86.37$ \\
\hline Farming experience & & $0.04^{*}$ & 1.12 & $1.01-1.25$ \\
\hline Access to extension services & 1 vs 0 & $0.04^{*}$ & 0.20 & $0.03-1.65$ \\
\hline $\begin{array}{l}\text { Having the second generation } \\
\text { who likes to continue farming } \\
\text { activities }\end{array}$ & & 0.46 & 0.47 & $0.07-3.27$ \\
\hline \multirow{4}{*}{ Occupation } & $\begin{array}{l}\text { Non-agricultural labor } \\
\text { (NAL) vs farming }\end{array}$ & 0.28 & 6.65 & $0.14-312.17$ \\
\hline & $\begin{array}{l}\text { NAL vs government } \\
\text { employee }\end{array}$ & $0.08^{* *}$ & 0.35 & $0.02-6.16$ \\
\hline & $\begin{array}{l}\text { NAL vs private sector } \\
\text { employee }\end{array}$ & 0.48 & 0.94 & $0.05-15.42$ \\
\hline & N.A.L. vs self-employee & 0.19 & 4.56 & $0.26-80.22$ \\
\hline $\begin{array}{l}\text { Water scarcity during Maha } \\
\text { season }\end{array}$ & & 0.71 & 0.55 & $0.02-13.33$ \\
\hline Age of the respondents & & 0.41 & 1.03 & $0.95-1.10$ \\
\hline
\end{tabular}

${ }^{*}$ Significant at $5 \%$ level, ${ }^{* *}$ Significant at $10 \%$ level Source: Field Survey (2019)

Long-season crops such as pepper (Piper nigrum), betel (Piper betle), banana (Musa spp.) like crop varieties, short-season crops such as snake gourd (Trichosanthes cucumerina), bitter gourd (Momordica charantia), winged bean (Psophocarpus tetragonolobus), brinjal (Solanum melongena), okra (Abelmoschus esculentus), long bean (Vigna unguiculate), cassava (Manihot esculenta), higurala (Dioscorea spp.) like crop varieties and leafy vegetables such as Kang kung (Ipomoea aquatica) and gotukola (Centella asiatica) can be easily grown in this wetland area. Land 
preparation activities are mostly avoided during the wet season of the wetland, due to erosion. Zero tillage and digging using hoes like practices can also be practiced. Use of conservation agriculture in wetland farming, crop productivity and soil carbon sequestration can be increased. Although, the seasonal wetlands are highly fertile than conventional uplands, continuous cultivation of wetlands declines soil fertility. Thus, soil amendments can either be added separately or in combinations. Cattle manure is the most common soil amendment. A high application rate of organic manure is needed, because crop response to the manure is low at low application rates. Hence, combining cattle manure and inorganic fertilizers is important. In addition to cattle manure; termite mount soil and leaf litter are also much important in seasonal wetland cultivations. These are freely available; thus, useful to improve soil structure, water holding capacity, and to enhance crop growth. Additionally, locally available soil amendments like compost, which are made in home gardens using household wastes, and poultry manure can also be used. Most of the freely available amendments like termite mount soil, leaf litter, and compost are introduced to farmers, who cannot afford to inorganic fertilizers, cattle, and poultry manure. Burning of the stuff before land preparation and application of that biochar into the soil is also very important in wetland cultivations. Biochar stays in soil over a long period and hence, it helps to mitigate greenhouse gas emissions via enhancing carbon sequestration (Nyamadzawo 2015).

In addition to increasing carbon sequestration, biochar helps to enhance nutrient availability, soil structure, crop productivity, moisture retention, and finally helps in maintaining the fertility of the soil. Plant residues also have the potential to enhance fertility, soil quality, and carbon stocks (Nyamadzawo et al. 2015).

Raised beds and ridges and furrows are common in wetland cultivations for management of water. These practices were already used by the farmers in Kaduwela wetland area. Further, McCartney et al. (2005) also highlighted that the greatest benefits are likely to be achieved through ridge and furrow cultivation to avoid waterlogging and use small-scale irrigation. They do not practice crop rotation and in wetlands.

Mixed cropping is implied as a cropping technique in which different types of crops are cultivated together (Izac 1990). During mixed cropping, the risks are lower and easy to compensate. In the Kaduwela wetland area, a mixed cropping pattern is used for uplands. Intercropping patterns are also used by the farmers in uplands of Kaduwela wetland. Crop rotation is the growing of different crops on a piece of land to avoid exhausting the soil and to control weeds, pests, and diseases in a succession 
manner (Nyamadzawo 2015). According to the survey results, $76 \%$ of the farmers were practicing crop rotation and was common among small scale farmers. Certain farmers cultivate a single crop in large scale for commercial purposes and the proportion was $24 \%$.

Use of legume trees coupled with annual crops is a potential agroforestry option to be used in seasonal wetland cultivations. In Zimbabwe, cultivation of legume trees with maize has resulted a higher maize yield by increasing soil organic matter, reducing erosion, enhancing biological diversity, and improving the microclimatic conditions by allowing the associated crops to do well in extreme climatic conditions in wetlands (Nyamadzawo 2015). $\mathrm{NO}_{2}, \mathrm{CH}_{4}$, and $\mathrm{CO}_{2}$ emissions from wetlands are lowered and the $\mathrm{C}$ sink strength is enhanced by the usage of agroforestry practices in wetlands compared with conventional farming systems. In Malawi, Sesbania sesban was used well in seasonal wetland cultivations (Nyamadzawo et al. 2015). S. sesban tolerates waterlogging conditions during we season, while it can be used as a tree species during dry season. S. sesban is a legume; therefore, can be used as an alley crop, while it is a windbreaker and also provides shade and support for other crops. In addition, the integration of multipurpose trees like Gliricidia sepium into the cropping patterns can also be done.
Water scarcity common in this wetland during the Maha season, thus water conservation strategies must be implemented. Water conservation strategies that can be applicable are irrigation at sunset, mulching, deep planting, hand irrigation in cases of extreme drought, and potholing in the vegetable beds. These strategies help to manage soil water maximumly. In addition, use of early maturing and drought-tolerant varieties is also much important (Nyamadzawo et al. 2015).

\section{Conclusion}

The majority of the farmers are willing to cultivate upland crops in the Kaduwela wetland. Root and tuber crops (cassava, higurala), leafy vegetables (gotukola, kangkung), vegetables (brinjal, snake gourd, bitter gourd, okra, long bean, winged bean, chilli), and crops like pepper are grown by farmers mostly in home garden level. Inadequacy in supportive services, water scarcity, technological issues, price fluctuations, and transport problems during extreme weather situations are the major constraints in cultivating upland crop in Kaduwela wetland. Land extent, knowledge on environmentally friendly farming practices, knowledge on traditional farming practices, the farming experience of the household head, access to extension services, and nature of the occupation of the household head had determined the preference of cultivating upland crops by 
the farmers of Kaduwela wetland area. The majority of the farmers are willing to use conservation agricultural practices (i.e. land preparation activities, cropping patterns) as a measure of sustainable agriculture in Kaduwela wetland. Application of soil amendments, ridge and furrow land preparation, mixed cropping, and mulching are common management strategies in Kaduwela wetland.

\section{References}

Ajewole O C (2014) Risks and productivity constraints in wetland farming in Ekiti state, Nigeria. Journal of Applied Agricultural Research. 6(1): 37-47.

Anonymous (1999) Seasonal herbaceous wetlands (freshwater) of the temperate lowland plains listing advice Available at: http://www.environment.gov.au/biodiversi ty/threatened/communities/pubs/97-

listing-advice.pdf. accessed 15 February 2019.

Izac A M N, Swift M J, Andriesse W (1990) A strategy for inland valley agro- ecosystems research in West and Central Africa, RCMP Res. Monogr. 5. Int. Inst. Trop. Agric. (IITA) Ibadan Nigeria.

Masiyandima M, McCartney M P, and Van Koppen B (2004) Wetland contributions to livelihoods in Zambia. FAO Netherlands Partnership Program: Sustainable Development and Management of Wetlands. 50.
McCartney M P, Masiyandima M, HoughtonCarr H A (2005) Working wetlands: Classifying wetland potential for agriculture. Research Report 90. Colombo Sri Lanka: International Water Management Institute (IWMI).

McCartney M P and Houghton-Carr H A (2009) Working Wetland Potential: An index to guide the sustainable development of African wetlands. Natural Resources Forum 33: 99-110.

Ministry of Home Affairs http://www.kaduwela.ds.gov.lk/index.php/ en/statistical-information.html. accessed 15 February 2019.

Msusa H (2011) Sustainable Utilization of Wetlands for Food Security: A Case Study of the Simulemba Traditional Authority in the Kasungu District of Malawi. Journal of Developments in Sustainable Agriculture 6: 86-100.

Nyamadzawo G, Wuta M, Nyamangara J, Nyamugafata P, and Chirinda N (2015) Optimizing dambo (seasonal wetland) cultivation for climate change adaptation and sustainable crop production in the smallholder farming areas of Zimbabwe, International Journal of Agricultural Sustainability 13(1): 23-39.

Ramsar Convention Secretariat (2004) Ramsar handbooks for the wise use of wetlands. 2nd edition, Gland, Switzerland, Ramsar Convention Secretariat. 
Ramsar Convention Secretariat (2013) The Ramsar Convention Manual: a guide to the Convention on Wetlands (Ramsar, Iran, 1971) 6th edition, pp: 5-10, Ramsar Convention Secretariat, Gland, Switzerland. 